\title{
11. Greater exchange, greater ambiguity: Water resources data and information exchange in transboundary water treaties
}

\author{
Andrea K. Gerlak \\ University of Arizona, United States
}

Jonathon Lautze

International Water Management Institute, South Africa

\author{
Mark Giordarno \\ International Water Management Institute, South Africa
}

Effective management of the world's water resources is considered to require access to credible and reliable data and information regarding the state of the resource, and how it is affected by water use and development, land use practices and climate change (Bernauer and Kalbhenn 2010; Rogers and Hall 2003; Timmerman and Langaas 2005; Wolf 2007; United Nations Educational, Scientific and Cultural Organization (UNESCO) 2009).

Water resources data and information exchange is a key principle of the growing global normative framework for transboundary waters that shapes international law (Conca et al. 2006). Data and information exchange is an important design principle associated with the effectiveness of institutionalised cooperation (Zawahri 2008; Stinnett and Tir 2009). Joint water resources data and information gathering can alleviate disputes over data and prevent broader conflict (Bernauer and Kalbhenn 2010). Increasingly, using data and information to understand complex problems is seen as a key component of the successful governance of common pool resources and adaptive management strategies (Dietz et al. 2003; Raadgever et al. 2008).

The issue of access to data and information on transboundary water resources, i.e. basins and aquifers that are shared by two or more states, is particularly important given the potential for conflict. Despite international calls for data and information exchange in transboundary waters and for exchange of basinspecific evidence to support cooperative management, no systematic research has been undertaken to understand where, how frequently, or what water resources data and information are exchanged. 
Global Water: Issues and Insights

Table 1: Select examples of water resources data and information exchange

\begin{tabular}{|c|c|}
\hline Hydrologic data & $\begin{array}{l}1928 \text { Convention between the German Reich and the } \\
\text { Lithuanian Republic regarding the maintenance and } \\
\text { administration of the frontier waterways, which states } \\
\text { in article 10: "The ordinary water-gauge observations at } \\
\text { the usual observation posts shall be exchanged monthly } \\
\text { immediately on receipt of the water-gauge lists" }\end{array}$ \\
\hline Hydrologic information & $\begin{array}{l}1972 \text { Agreement relating to the establishment of a Canada- } \\
\text { United States committee on water quality in the St. } \\
\text { John River and its tributary rivers and streams that cross } \\
\text { the Canada-United States boundary in article } 1 \text { that the } \\
\text { committee should "exchange appropriate information about } \\
\text { plans, programs, and actions which could affect water } \\
\text { quality in the Basin" }\end{array}$ \\
\hline $\begin{array}{l}\text { Research, investigations, and } \\
\text { assessments }\end{array}$ & $\begin{array}{l}1957 \text { Agreement between Iran and the Soviet Union for the } \\
\text { joint utilization of the frontier parts of the rivers Aras and } \\
\text { Atrak for irrigation and power generation, which states that } \\
\text { "both parties hereto agree jointly to carry out exploration } \\
\text { of the rivers Aras and Atrak all along the border common } \\
\text { to the USSR and Iran and accumulate technical data related } \\
\text { to their respective flows. They also agree to carry out } \\
\text { necessary outdoor and indoor studies for the preparation of } \\
\text { preliminary plans for irrigation and power generation from } \\
\text { the strait of Ghis Ghalasi up to the end of the frontier of the } \\
\text { river Aras and all frontier parts of the Atrak River" }\end{array}$ \\
\hline $\begin{array}{l}\text { Unspecified type as general } \\
\text { reports }\end{array}$ & $\begin{array}{l}2004 \text { Agreement on the Establishment of the Zambezi } \\
\text { Watercourse Commission, which includes provision to } \\
\text { "collect, evaluate and disseminate all data and information } \\
\text { on the Zambezi Watercourse as may be necessary for the } \\
\text { implementation of this Agreement" }\end{array}$ \\
\hline Prior notification & $\begin{array}{l}1994 \text { OKACOM agreement on the Okavango basin in } \\
\text { southern Africa. Article } 1 \text { addresses prior notification, calling } \\
\text { for signatories to "notify the Commission of any proposed } \\
\text { development or other matter which falls within the function } \\
\text { of the Commission"' }\end{array}$ \\
\hline Formalized communication & $\begin{array}{l}1994 \text { OKACOM agreement on the Okavango basin in } \\
\text { southern Africa. The agreement establishes "a commission } \\
\text { which will have formal meetings for sharing information and } \\
\text { concern" }\end{array}$ \\
\hline
\end{tabular}

Source: Authors' research.

In a recent piece of research (Gerlak et al. 2011), we examined the content of all known and available transboundary water treaties signed between 1900 and 2007 in order to formally assess the sanctioned exchange of data and information in transboundary water settings.

For the purposes of the study, data are defined as 'hard' numbers relating to water resources, such as rates of river flow and levels of water quality. Information is defined more broadly as general qualitative information, such as communication that a flood is impending or other conclusions reached from the analysis of 
hard data. A third type of data and information exchange includes provisions to conduct joint research, investigations and assessments that include, or could be inferred to include, some aspects of data and information exchange.

In addition to these direct mechanisms for data and information exchange, we also examined more indirect mechanisms including prior notification provisions and formalised communication. Prior notification refers to treaty provisions for prior consultation, notification or consent of planned measures related to water. Formalised communication refers to provisions for joint management institutions, regular political consultations, consultations as conflict resolution measures and arbitration. Table 1 provides some examples of water resources data and information exchange identified in the study.

Table 2: Indirect and direct data and information exchange mechanisms ( $N=287$ )

\begin{tabular}{|l|l|l|}
\hline \multicolumn{2}{|l|}{ Direct water resources data and information exchange } & $37 \%(106)$ \\
\hline \multirow{2}{*}{$\begin{array}{l}\text { Indirect water resources data } \\
\text { and information exchange }\end{array}$} & Prior Notification & $87 \%(248)$ \\
\cline { 2 - 3 } & Formalized Communication & $90 \%(259)$ \\
\hline
\end{tabular}

Source: Adapted from Gerlak et al. 2011. $\mathrm{N}=$ number of total treaties investigated. Treaties may include more than one type of information exchange mechanism.

In cases where the exchange of hard data could not be specifically identified, agreements were classified as exchanging only information. As such, records of information exchange in the study may contain exchanges of data where data is not explicitly mentioned in the treaty. The frequency with which data and information are exchanged is divided into one of four categories: (a) regular, (b) event triggered, (c) on demand, or (d) unclear.

The findings of our research suggest that, while complete data and information exchange does not occur globally, most transboundary water treaties have some mechanism for exchanging water resources data or information. Interestingly, however, despite the importance of data and information exchange for transboundary water resources, the results also suggest that states continue to largely rely on indirect mechanisms to share and exchange data, including prior notification and formalised communication. As Table 2 indicates, for example, only 37 per cent, or 106 of the 287 treaties investigated include direct data and information exchange mechanisms.

Looking at how treaties have changed over time, we find that the use of direct mechanisms for exchange has increased from less than 20 per cent in the preWorld War II period to more than 50 per cent in the post-Cold War era. The most notable increases in the use of direct exchange mechanisms occurred during the 1930s to 1940s, and a consistent increase in their use was observed from the 1970s through to the present (Figure 1). 
The latter of these two trends might suggest that the 1966 Helsinki Rules on the Uses of the Waters of International Rivers and 1997 UN Convention on the Law of Non-Navigational Uses of International Watercourses may play a role in influencing basin-level exchange.

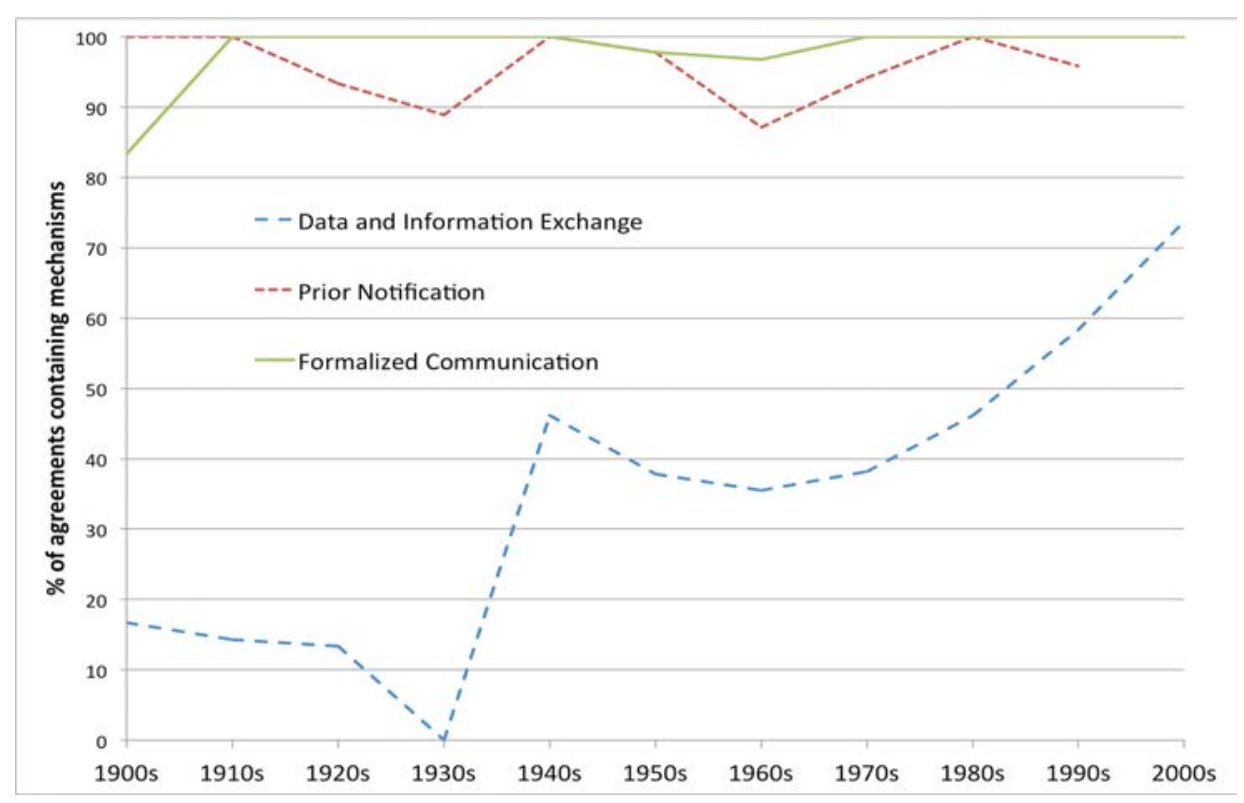

Figure 1: Direct and indirect mechanisms for water resources data and information exchange by decade (per cent of agreements)

Source: Adapted from Gerlak et al. 2011.

Looking at the different types and functions of transboundary water treaties, the results suggest that data and information exchange in procedural and generative treaties have seen the greatest rise. Procedural agreements are those that provide frameworks for regular, collective decision-making (e.g., joint water management committees) while generative agreements develop new social practices (e.g., establishing principles, such as 'no significant harm'). As such, we find that water resources data and information exchange is correlated with changes in the goals and nature of treaties themselves.

In addition, we observe exchanges occurring in all geographic regions of the world. While, however, exchange in transboundary settings is not unique to democracies, the results suggest that democracies have a greater frequency of exchange than autocracies or other types of regime. This suggests that common values do help to reduce transaction costs in seeking solutions to collective action problems (Agrawal 2002), and that democracies, which may be more attentive to demands from constituents for cooperation and transparency, are therefore more likely to agree to share information in the first place (Shanks et al. 1996). 
Overall, our research suggests a convergence towards inclusion of water resources data and information exchange as a key component of water treaties. This movement towards a more formal, direct exchange of data and information represents a key principle of an emerging governing framework for shared river basins (Conca et al. 2006).

\section{Table 3: Frequency of direct water resources data and information exchange}

\begin{tabular}{|l|c|}
\hline Frequency & Percent of frequencies of exchange (N=111) \\
\hline Regular exchange & $29 \%(32)$ \\
\hline Event-triggered & $9 \%(10)$ \\
\hline On request, as needed & $16 \%(18)$ \\
\hline Unclear & $46 \%(51)$ \\
\hline
\end{tabular}

Source: Adapted from Gerlak et al. 2011.

While, however, we observe a growing trend for data and information exchange, we also find that only 29 per cent of agreements call for regular exchange of data or information; that is, with particular intervals defined, such as every six months or annually (Table 3). It appears, therefore, that states prefer unclear, event-triggered, and on-request exchange mechanisms to regular data exchange. This suggests a reluctance on the part of many states to formally legalise detailed schedules for exchange. Future research could therefore investigate the underlying causes or reasons for this hesitation around regular exchange and its implications for transboundary water management.

In conclusion, while our research suggests that states are increasingly engaging in data and information exchange in transboundary water agreements, we have uncovered a reluctance on the part of many states to legalise formal schedules for exchange. This ambiguity in terms of the frequency of exchange is consistent with earlier research on international water resources that suggests that states may intentionally design vague mechanisms related to data exchange in order to allow for greater flexibility in the face of resource uncertainty, or to serve domestic political purposes (Fischendler 2008). While it may have political benefits, this level of ambiguity may also trigger questions over the meaningfulness of irregular data and information exchange, and require closer examination from both academics and water policy decision-makers.

Andrea K. Gerlak is the Director of Academic Development with the International Studies Association and Policy Associate with the Udall Center for Studies in Public Policy at the University of Arizona. 
Global Water: Issues and Insights

Jonathan Lautze is a Researcher at the International Water Management Institute Southern Africa office in Pretoria.

Mark Giordano is Director of Water and Society Research at the International Water Management Institute. This article is a summary version of 'Water resources data and information exchange in transboundary water treaties', International Water Agreements 11:179-99. For more information, please contact Andrea K. Gerlak at agerlak@u.arizona.edu.

\section{References}

Agrawal, A., 2002. 'Common resources and institutional sustainability', in E. Ostrom, T. Dietz, N. Dolsak, P.C. Stern, S. Stonich and E.U. Weber (eds), The Drama of the Commons, Washington, D.C: National Academy Press, pp. 41-85.

Bernauer, T. and Kalbhenn, A., 2010. 'The politics of freshwater resources', in R.A. Denemark (ed.), The International Studies Encyclopedia, Wiley-Blackwell Publishers, Oxford, pp. 5800-21.

Conca, K., Wu, F. and Mei, C., 2006. 'Global regime formation or complex institution building? The principled content of international river agreements', International Studies Quarterly 50:263-85.

Dietz, T., Ostrom, E. and Stern, P.C., 2003. 'The struggle to govern the commons', Science 302:1907-10.

Fischhendler, I., 2008. Ambiguity in transboundary environmental dispute resolution: the Israeli-Jordanian water agreement', Journal of Peace Research 45(1):91-110.

Gerlak, A.K., Lautze, J. and Giordano, M., 2011. 'Water resources data and information exchange in transboundary water treaties', International Environmental Agreements 11:179-99.

Raadgever, G.T., Mostert, E., Kranz, N., Interwies, E. and Timmerman, J.G., 2008. 'Assessing management regimes in transboundary river basins: do they support adaptive management?', Ecology and Society 13(1):14.

Rogers, P. and Hall, A.W., 2003. Effective Water Governance, Global Water Partnership, Stockholm.

Shanks, C., Jacobson, H.K. and Kaplan, J.F., 1996. 'Inertia and change in the constellation of international governmental organizations, 1981-1992', International Organization 50(4):593-627. 
Stinnett, D. and Tir, J., 2009. 'The institutionalization of river treaties', International Negotiation 14(2):229-51.

Timmerman, J.G. and Langaas, S., 2005. 'Water information — what is it good for? On the use of information in transboundary water management', Regional Environmental Change 5(4):177-87.

United Nations Educational, Scientific and Cultural Organization (UNESCO), 2009. United Nations World Water Development Report 3: Water in a Changing World, Paris, France.

Wolf, A.T., 2007. 'Shared waters: conflict and cooperation', Annual Review of Environment and Resources 32:3.1-3.29.

Zawahri, N.A., 2008. 'Designing river commissions to implement treaties and manage water disputes: the story of the joint water committee and permanent Indus Commission', Water International 33(4):464-74. 
This text taken from Global Water: Issues and Insights by R. Quentin Grafton, Paul Wyrwoll, Chris White and David Allendes, published May 2014 by ANU Press, The Australian National University, Canberra, Australia. 